\title{
Compliance and Enforcement Challenges in the National Building Regulations' Processes of South Africa
}

\author{
FETNANI CECILIA
}

\begin{abstract}
The chapter discusses the compliance and enforcement processes of the National Building Regulations of South Africa. These processes are administered by the National Regulator for Compulsory Specifications (NRCS) in terms of the National Building Regulations and Building Standards Act 103 of 1977 (The Act). The objective was to investigate the how the business processes by the NRCS have enforced Building Control Officers at the Local Authorities nationwide to comply with the safety of buildings for building occupants or end-users. The investigation was largely motivated by the high number of injuries, deaths and/or human lives affected and reported due to collapsing and defective buildings. It was a case study based on disasters occurred and reported at various Local Authorities, in private residential homes, government-owned buildings, abandoned and commercial buildings, such as shopping malls. This study was conducted using discussions and survey with affected stakeholders. The stakeholders ranged from building owners, prospective building owners and/or building occupants, built-environment practitioners, Local Authorities' Building Control Officers and the Regulator. The relevant information was gathered in an ethical manner and for the intended study only. The empirical findings revealed that there was a critical need for business process review and strategy shifts that advance objectivity and benefits to compliance, visibility and awareness of regulatory process. The output is a proposed re-design of NRCS business processes that can effectively enforce compliance of the building regulations of South Africa.
\end{abstract}

Keywords: Compliance; enforcement challenges; National building regulations; commercial buildings.

\section{INTRODUCTION AND HISTORICAL CONTEXT OF THE PHENOMENON}

The objective of this chapter is to determine the factors contributing to the effectiveness of the national building regulations on the built-environment to ensure buildings are of safety, healthy, meet environmental requirements and suitable for human occupancy. This is driven by affected stakeholders' perceptions and experiences in the built-environment. Furthermore, the investigation was based on the following:

1. How do business processes assist in implementing the provisions of the National Building Regulations and Building Standards Act 103 of 1977 (hereafter called "the Act") to ensure buildings are safe and habitable for humans?

2. In terms of the Act, how do different management processes enable the Regulator to deliver on its mandate and ensure end-users or building occupants' safety is assured when they enter buildings?

3. Why do buildings collapse when there are building regulations?

4. The following are some of the cases that have suggested challenges of the buildings approval core business processes in the identified countries, i.e.

(a) "Tongaat Mall foreman pleads ignorance" (IOL News, 2014);

(b) "Egypt building collapse kills 17 people" (BBC Online News, 2014);

(c) "Egyptian residential block collapses leaving at least 23 dead" (The Guardian Online News, 2013);

(d) "Bangladesh building collapse death toll passes 500" (BBC Online News, 2013); 
(e) "Brazil commercial building collapses, kills 6" (CP24 Online News, 2013): August 27, 2013-".

Given the above cases, related scholarly work on the compliance and enforcement business processes of building regulations were reviewed to establish whether the existing challenges within the built-environment had been addressed before. It was also to gain the general understanding of the phenomenon and also to determine whether the current processes are obsolete and inadequate or not. Preliminary investigation on National Building Regulations by Watermeyer and Milford, (2004) outlined that administrative processes and procedures of building regulations were promulgated to ensure that functional requirements within the built-environment are met for safety of buildings, thus substantiating the need to revise a framework that makes use of business process to effectively and efficiently implement the provisions of the Act. Given Watermeyer and Milford statement, it is arguable that business process re-engineering (BPR) is one of the techniques universally accepted as remedies to all problems faced by organizations, including challenges of processes and systems inefficiencies as alluded to by Atreya (2012). Atreya (2012), Thong (2014), Marija and Kiril (2012) further argue that BPR is technique that can successful measure and bring about radical changes (i.e., under political and social pressures), improved performance and able to achieve results. Furthermore, Sommerville (2012) also argues that system, including both hardware and software components, define operational processes within the parameters of, and limited to, the functions of the organisation. Thus, drawing from Sommerville, it is arguable that processes drives systems development and as such systems facilitates process implementation. Another study by Windapo and Rotimi (2012) outlined the adverse impact the lack of implementation of efficient and effective processes of the Building Regulations had on building structures, its infrastructure and to the occupants of various types of buildings, as well as the economic impact.

Therefore, a review of the core business processes of the National Building Regulations of South Africa in general was undertaken to gain understanding of the phenomenon. One of the processes was thus engaged to verify its effectiveness in ensuring the safety of buildings and consequently protecting the end-users, building owners or building occupants. Laubscher (2011) in his study of the origins of the building regulations in Southern Africa pointed out that, due to additional health requirements being prescriptive on certain aspects of buildings and all and building infrastructure, catastrophic events had proven to occur where the regulatory processes are proven to be ineffective. To understand and interpret the phenomenon, a problem conceptualization was developed (see Fig. 1) that led to processes verification using process mapping and modelling to determine the effectiveness business processes that are to ensure safety of buildings.

Given the Fig. 1 there is a problem with this business process as it is internalized to the administrative objectives of the NRCS in exclusion of 3 other stakeholders, namely: (a) the Building Control Officers, (b) Built-environment Practitioners - Regulated parties in terms of "the Act," and (c) End-usersbuilding owners or occupants whose safety must be ensured against defective or structurally unsound buildings. The problem conceptualization is thus described as follows:

1. The process outlines 4 (four) key activities of national building regulations business unit that are concluded without reflecting any direct impact on the end-user in ensuring the safety of buildings and that of building occupants;

2. No sanctioning sub-process is outlined in cases where non-compliance to any of the applicable Building Regulations are identified

3. The process above does not show any stakeholder engagement sub-process.

Given the above description, it is thus arguable that there are gaps in the business processes which have resulted in the effectiveness and inefficiencies of the Building Regulations and "the Act" in regulating the built-environment. Although there is limited literature on building's regulatory business processes, it can still be deduced that there are gaps in the current business processes of national building regulations in South Africa. 


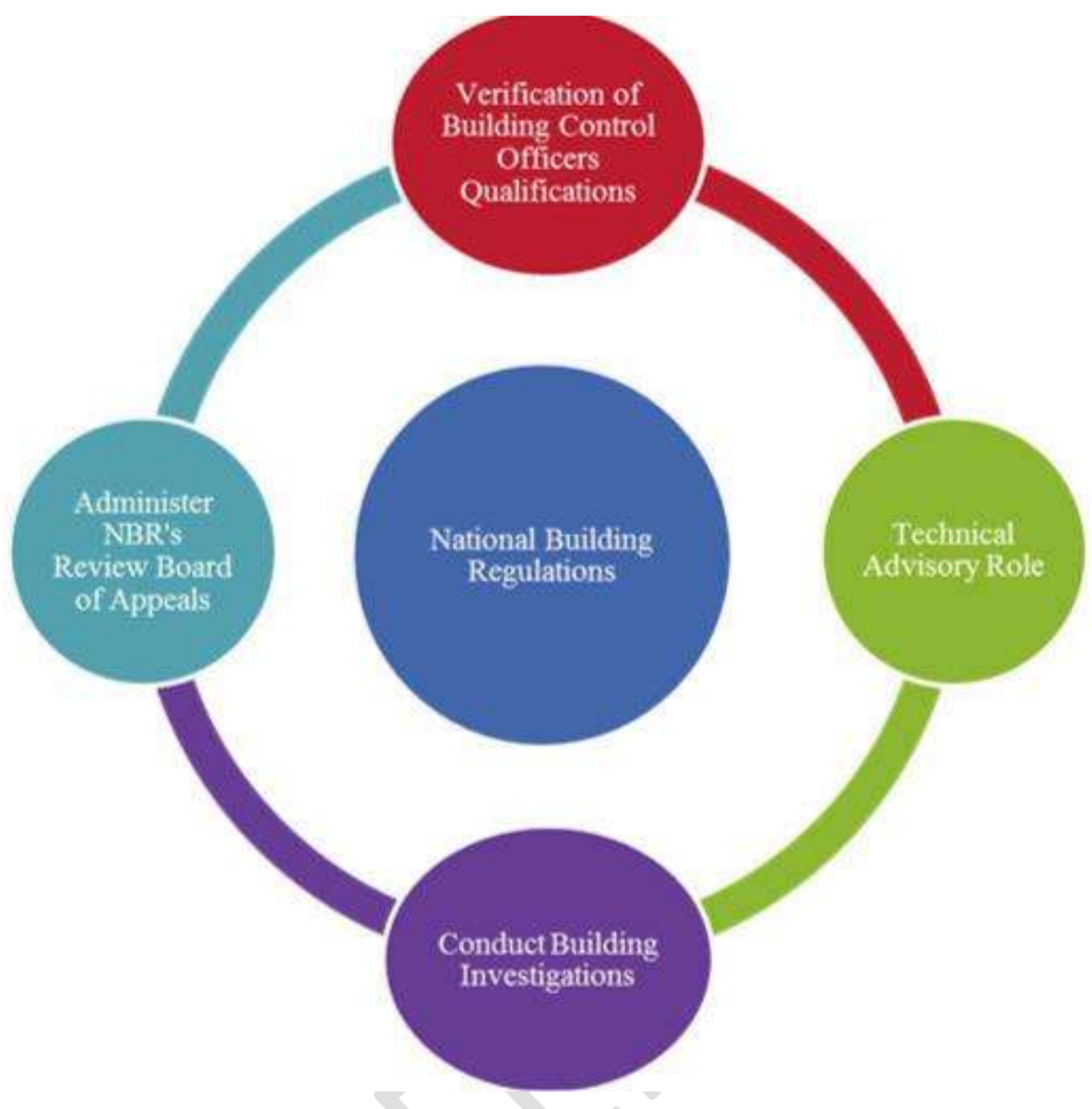

Fig. 1. Problem conceptualization

\section{ANALYSING THE PHENOMENON}

The phenomenon was analysed using a case study based on 4 (four) stakeholder groups affected by "the Act" and its Building Regulations categorised in Levels 1 (one) to 4 (four) as fully described below in Table 1. Stakeholder representatives were randomly selected from various stakeholder groups with reference to the current study. The approach provided the tools to analyse the built-environment within the context of National Building Regulations (Baxter and Jack, 2008).

\section{Table 1. Stakeholder categories and referencing}

\begin{tabular}{|c|c|}
\hline Category & Stakeholder reference \\
\hline Level 1 & Building Owners / Prospective Building Owners / Building Occupants \\
\hline Level 2 & $\begin{array}{l}\text { Built-environment Practitioners - architects, builders, engineers, legal } \\
\text { representatives as } \\
\text { appointed by the prospective or the building owner; }\end{array}$ \\
\hline Level 3 & $\begin{array}{l}\text { Local Authorities' Building Control Officers - represented by the Building Control } \\
\text { Officers }\end{array}$ \\
\hline Level 4 & $\begin{array}{l}\text { NRCS - The Regulator of the National Building Regulations - the National Regulator } \\
\text { for } \\
\text { Compulsory Specification }\end{array}$ \\
\hline
\end{tabular}

In cognizance of the problem conceptualization, an interactive approach by means of one-on-one discussions with stakeholders at various levels as referenced in Table 1 was used. Forty (40) stakeholders in the built-environment and its related business owners participated in the discussions; 
10 in each level participated voluntarily. Tremendous insight into the regulations was gained in the built-environment. The discussions aimed at:

1. Assisting in understanding and interpreting the catastrophic incidents occurring within the built-environment and building industry within the ambit of the National Building Regulations;

2. Re-evaluating the status quo of the implementation of the National Building Regulations; and

3. Developing interventions where gaps and inadequacies are identified in the study, resulting in the recommendations for re-designing of core business processes of the National Building Regulations.

This interactive approach was relevant and appropriate for the intended study to establish the perceptions and experiences of all affected stakeholders on the understanding and implementation of the core national building regulations' business processes within the built environment in South Africa.

The relevant information obtained was thus verified based on the following factors at each stakeholder level: (a) knowledge about the Building Regulations, (b) generic and technical understanding of the application of the Building Regulations, (c) highlights the benefits of the Regulations, (d) highlights the gaps and the limitations of the Regulations and regulatory processes, (e) proposes the mitigation where shortcomings are identified and enhances the current status quo where quick wins are highlighted, (f) highlights the impact of compliance as well as that of non-compliance; and (g) flags the areas of improvement.

\section{REGULATORY COMPLIANCE AND ENFORCEMENT}

The analysis of information was based on the responses received from all 4 (four) stakeholders at all levels affected by "the Act" and its building regulations who were randomly selected to answer the questionnaire based on the analysis of the phenomenon of which the study was based on. Thus, it discusses the impact of the implementation of national building regulations' business processes in ensuring that buildings are safe, healthy, and environmentally friendly and are of sound quality for human occupancy. All selected participants proved to have been affected by the regulations of building in one form or another as outlined and defined in Table 1. It was also established during the information gathering that they understood how the regulations impacted on their lives when the industry is regulated. The following were acknowledged:

1. Participants displayed a generally low level of awareness and understanding of the regulatory role of implementation of National Building Regulations. This primarily is projected from the building owners' input not recognizing the government's imperative in ensuring safe buildings, and further to consider the government's imperative as an essential and a basic benefit to citizens at large.

2. Communication channels between the stakeholders and the regulator were inadequate are based on internal business processes and systems which are already ineffective.

3. There are inconsistencies of the enforcement of the legislation by various local authorities.

4. Significant differences were recorded by the respondents at different stakeholder levels in terms of thorough understanding of the regulatory dynamics in ensuring the implementation of the Regulations; this was indicated as crucial.

5. A high level of non-responses was noted where stakeholders at various levels repeatedly stated that they were not aware of various regulatory and business processes. This highlights the importance of the need to sensitize all citizens of the critical nature of the legislation, and how it impacts on all citizens' day-to-day lives as all citizens are automatically occupants to one form of building or another.

6. Participants at all levels suggested that implementers of the building regulations must ensure that their business processes and systems promote compliance to the legislation to support the safety, health and environmentally friendly buildings for human occupancy, as intended.

7. The stakeholders agreed that the regulator must periodically assess the understanding of the stakeholders towards the implementation of building regulations to address perceptions of the regulatory business processes and systems in relation to the legislation. 
8. The NRCS - NBR Business Unit must use process mapping and process modelling in the design and redesign of processes and systems management.

9. It was confirmed that NRCS - NBR Business Unit must collaborate with customers, stakeholders and end-users that have had no understanding of its business processes upstream and downstream processes - to avoid the problem of miscommunications, gaps, redundancies, workarounds, rework loops and waste.

In view of the results from the analysed information and subsequent recommendations, a redesigned of the core business processes of the building regulations to effectively and efficiently regulate the built-environment is proposed (Fig. 2).

In general, the participants, at all stakeholder levels, in the study expressed that the National Building Regulations and building standards within the built environment face major challenges and obstacles. The general lessons learned from the analysis of information were seen in the following key points, which are significant to the future of safe, healthy, environmentally friendly buildings of sound quality for human occupancy:

(a) Stakeholder consultations in the core regulatory business processes' development and/ or redesigning in line with the relevant building regulations;

(b) Stakeholder awareness forming part of the core regulatory business process for all affected stakeholders at all levels;

(c) Uniformity in understanding, interpretation and implementation of the building regulations and its core regulatory processes;

(d) Awareness and understanding of the regulatory framework in line with the Act; and

(e) Adequate support measures and robust monitoring tools, which will lead to commitment to the effective implementation of the Regulations by the regulators and enforcers of the Act.

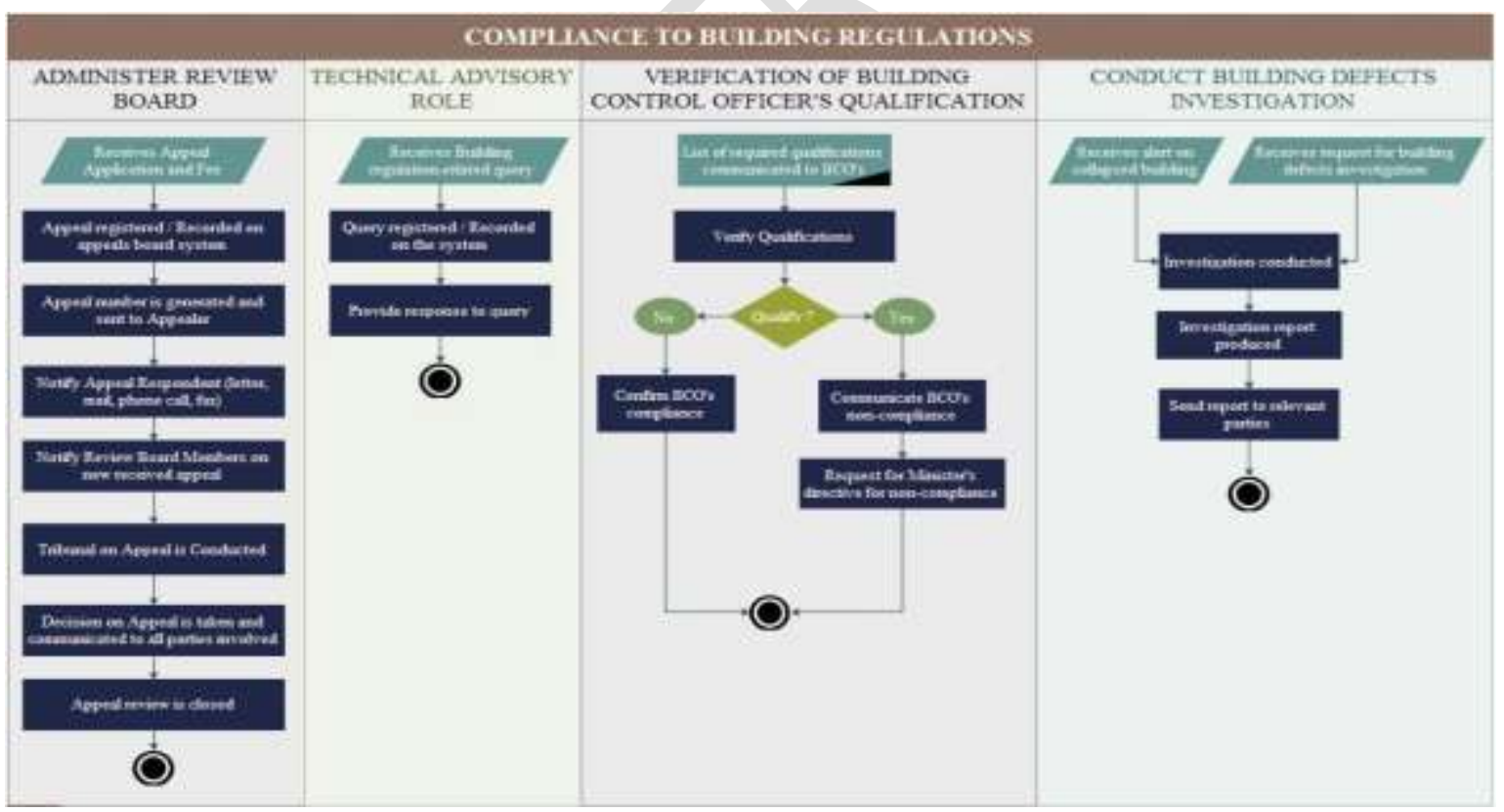

Fig. 2. Proposed Re-designed of NRCS_NBR Business Unit's regulatory business processes

It is thus recommended that the NRCS - National Building Regulations Business Unit redesigns its core business processes of the National Building Regulations of South Africa to outline and include the following: (a) Stakeholder Liaison, (b) Introduce the sanction sub process for identified noncompliances to "the Act" and its building regulations, and (c) State the output of the entire business process which would be safe, healthy buildings that meet environmental requirements and are suitable for human occupancy. 


\section{CONCLUSION}

One of the objectives of this paper was to propose re-designed core business processes of the National Building Regulations of South Africa as outlined below in Fig. 2. The latter was alluded to earlier in this paper to ensure effective compliance and enforcement of regulations within South Africa's built-environment. The paper argues that the status of the outcome of implementation of redesigned core regulatory business processes will determine the stakeholders' satisfaction or dissatisfaction. Within the built-environment, stakeholders may vary from the building owner/occupant or end-user, Building Control Officers from Local Authorities, the built-environment's practitioner to the NRCS - NBR Business Unit. Implementation of redesigned business processes by the NRCS NBR Business Unit resulting in the effectiveness and efficiency in regulating the built-environment ensuring the safety of buildings. Since the purpose of the regulatory processes is to ensure that the built environment is effectively and efficiently regulated, instances of non-compliance should be remedied with alternatives to ensure that building occupants are protected from defective buildings.

With the limited and insufficient studies conducted around Building Regulations and the implementation of the core regulatory business processes thereof; it is concluded from both Laubscher (2011) and Watermeyer (2010:6) that the future debate should focus on redesigning of regulatory business processes. That will enable uniformity in understanding, interpretation and implementation of the legislation, i.e. the Act, to ensure that buildings are healthy, safe, meet environmental requirements and are of sound quality for human occupancy. Future research and developments should further focus on:

(a) Inclusion of stakeholder consultations and awareness as a sub-process in the re-designed processes;

(b) Clearly in re-defining the roles, responsibilities and accountability of all affected stakeholders, including the end-user's benefactor in the administrative Charter where the legislation may not be promptly amended;

(c) Analysing the Regulations, regulatory framework and business processes;

(d) Evaluating the effectiveness of the role which the Building Regulations, and its business processes, can play in ensuring the safety of building occupants, preventing collapsing of buildings and defective buildings;

(e) analysing the dynamics underlying the strategic repositioning of stakeholders at all levels within the built-environment, as a result of Building Regulations and effective implementation of its core business processes; and

(f) Broadening the application of the core regulatory business processes by analysing other regulated environments, e.g. the Electro-Technical Industry, while remaining mindful that the simple adaptation of the redesigned core business processes within the built environment is to address the problem effectively.

\section{REFERENCES}

Setiawan, Adib Rifqi. (2017, February 24). Penerapan Pendekatan Saintifik untuk Melatihkan Literasi Saintifik dalam Domain Kompetensi pada Topik Gerak Lurus di Sekolah Menengah Pertama. Undergraduate Thesis. Bandung: Universitas Pendidikan Indonesia. URL: http://repository.upi.edu/29074/

Setiawan, Adib Rifqi. (2020, April 21). Lembar Kegiatan Literasi Saintifik untuk Pembelajaran Jarak Jauh Topik Penyakit Coronavirus 2019 (COVID-19). Edukatif: Jurnal Ilmu Pendidikan, 02(01): 28-37. DOI: https://doi.org/10.31004/edukatif.v2i1.80

Setiawan, Adib Rifqi. (2020, March 01). Pendidikan Literasi Finansial Melalui Pembelajaran Fiqh Mu'āmalāt Berbasis Kitab Kuning. Nazhruna: Jurnal Pendidikan Islam, 03(01): 138_159. DOI: https://dx.doi.org/10.31538/nzh.v3i1.522 
Setiawan, Adib Rifqi. (2020, January 24). Pembelajaran Tematik Berorientasi Literasi Saintifik. Jurnal Basicedu: Journal of Elementary Education, 04(01): 71-80. URL: https://jbasic.org/index.php/basicedu/article/view/298

Setiawan, Adib Rifqi. (2019, December 30). Instrumen Penilaian Pembelajaran Fiqh Mu'āmalāt Berorientasi Literasi Finansial. Eklektik: Jurnal Pendidikan Ekonomi dan Kewirausahaan, 02(02): 258-272. DOI: http://dx.doi.org/10.24014/ekl.v2i2.8117

Setiawan, Adib Rifqi. (2019, December 20). Literasi Saintifik Berdasarkan Kecerdasan Majemuk dan Motivasi Belajar. Media Penelitian Pendidikan: Jurnal Penelitian dalam Bidang Pendidikan dan Pengajaran, 13(02): 126-137. DOI: http://dx.doi.org/10.26877/mpp.v13i2.4913

Setiawan, Adib Rifqi; Puspaningrum, Mita; \& Umam, Khoirul. (2019, December 06). Pembelajaran Fiqh Mu'āmalāt Berorientasi Literasi Finansial. Tarbawy: Indonesian Journal of Islamic Education, 06(02): 187-102. URL: https://ejournal.upi.edu/index.php/tarbawy/article/view/20887

Setiawan, Adib Rifqi. (2019, October 02). Efektivitas Pembelajaran Biologi Berorientasi Literasi Saintifik. Thabiea : Journal of Natural Science Teaching, 02 (02): 83-94. DOI: http://dx.doi.org/10.21043/thabiea.v2i2.5345

Setiawan, Adib Rifqi. (2019, September 30). Instrumen Penilaian untuk Pembelajaran Ekologi Berorientasi Literasi Saintifik. Assimilation: Indonesian Journal of Biology Education, 02(02): 42-46. DOI: https://dx.doi.org/10.17509/aijbe.v2i2.19250

Setiawan, Adib Rifqi; Mufassaroh, Arij Zulfi. (2019, June 28). Menyusun Soal Literasi Saintifik untuk Pembelajaran Biologi Topik Plantae dan Animalia. BIOSFER: Jurnal Biologi dan Pendidikan Biologi, 04(01): 33-40. URL: http://dx.doi.org/10.23969/biosfer.v4i1.1484

Setiawan, Adib Rifqi. (2019, June 26). Peningkatan Literasi Saintifik melalui Pembelajaran Biologi Menggunakan Pendekatan Saintifik. Journal of Biology Education, 02(01): 223-235. URL: http://journal.stainkudus.ac.id/index.php/jbe/article/view/5278

Setiawan, Adib Rifqi; Utari, Setiya; Nugraha, Muhamad Gina. (2017, September 22). Mengonstruksi Rancangan Soal Domain Kompetensi Literasi Saintifik Siswa SMP Kelas VIII pada Topik Gerak Lurus. Wahana Pendidikan Fisika, 02(02): 44-48. URL: https://ejournal.upi.edu/index.php/WPF/article/view/8277/0

Setiawan, Adib Rifqi. (2020, April 20). Menyusun Instrumen Penilaian untuk Pembelajaran Ekologi Berorientasi Literasi Saintifik. Prosiding Seminar Nasional dan Workshop BiologiIPA dan Pembelajaran Ke-4 (SnoWBel IV): 241-9. ISBN : 978-602-470-170-3 \& eISBN : 978-602-470-171-0.

Setiawan, Adib Rifqi. (2020, February 18). Menyusun Instrumen Penilaian untuk Pembelajaran Topik Lingkungan Berorientasi Literasi Saintifik. Prosiding Seminar Nasional Fisika (SiNaFi) 2019: 15-21. URL: http://proceedings.upi.edu/index.php/sinafi/article/view/563

Setiawan, Adib Rifqi. (2020, January 17). Penggunaan Mabadi 'Asyroh dalam Pembelajaran Biologi untuk Meningkatkan Motivasi dan Hasil Belajar. Prosiding Seminar Nasional Biologi 2019 Inovasi Penelitian dan Pembelajaran Biologi III (IP2B III): 158-164. URL: http://semnasbiologi.conference.unesa.ac.id/ocs/index.php/semnasbio/IP2BIII/paper/v iewFile/11/21

Setiawan, Adib Rifqi. (2020, January 17). Upaya Meningkatkan Motivasi Belajar dalam Pembelajaran Ilmu Pengetahuan Alam (IPA) Melalui Bacaan Populer. Prosiding Seminar Nasional Biologi 2019 Inovasi Penelitian dan Pembelajaran Biologi III (IP2B III): 154-157. 
URL:

http://semnasbiologi.conference.unesa.ac.id/ocs/index.php/semnasbio/IP2BIII/paper/v iewFile/5/51

Setiawan, Adib Rifqi. (2020, January 17). Penerapan Pendekatan Saintifik dalam Pembelajaran Biologi sebagai Upaya Melatih Literasi Saintifik. Prosiding Seminar Nasional Biologi 2019 Inovasi Penelitian dan Pembelajaran Biologi III (IP2B III): 140-145. URL: http://semnasbiologi.conference.unesa.ac.id/ocs/index.php/semnasbio/IP2BIII/paper/v iewFile/6/19

Setiawan, Adib Rifqi. (2019, October 14). Penyusunan Program Pembelajaran Biologi Berorientasi Literasi Saintifik. Seminar Nasional Sains \& Entrepreneurship VI (SNSE VI): 255-18. URL: http://conference.upgris.ac.id/index.php/snse/article/view/255

Setiawan, Adib Rifqi. (2019, May 07). Penerapan Pendekatan Saintifik untuk Melatih Literasi Saintifik dalam Domain Kompetensi pada Topik Gerak Lurus di Sekolah Menengah Pertama. Prosiding Seminar Nasional Fisika (SiNaFi) 2018: 7-13. URL: http://proceedings.upi.edu/index.php/sinafi/article/view/355

Setiawan, Adib Rifqi. (2019, November 23). Profil Literasi Saintifik Berdasarkan Kecerdasan Majemuk dan Motivasi Belajar. Seminar Nasional Fisika V (SiNaFi 5.O), Universitas Pendidikan Indonesia (UPI). DOI: https://dx.doi.org/10.35542/osf.io/m7n95

Setiawan, Adib Rifqi. (2019, November 23). Menyusun Instrumen Penilaian untuk Pembelajaran Topik Lingkungan Berorientasi Literasi Saintifik. Seminar Nasional Fisika V (SiNaFi 5.0), Universitas Pendidikan Indonesia (UPI). DOI: https://dx.doi.org/10.35542/osf.io/sc6d2

Setiawan, Adib Rifqi. (2019, November 23). Analisis Keabsahan dan Keandalan Science Motivation Questionnaire II (SMQ II) Versi Bahasa Indonesia. Seminar Nasional Fisika V (SiNaFi 5.0), Universitas Pendidikan Indonesia (UPI). DOI: https://doi.org/10.31237/osf.io/6zeph

Setiawan, Adib Rifqi. (2019, October 05). Menyusun Instrumen Penilaian untuk Pembelajaran Ekologi Berorientasi Literasi Saintifik. Seminar Nasional \& Workshop Biologi, IPA, dan Pembelajarannya ke-4 (SnoWBel IV), Universitas Negeri Malang (UM). DOI: https://dx.doi.org/10.13140/RG.2.2.21931.39206

Setiawan, Adib Rifqi. (2019, August 21). Penyusunan Program Pembelajaran Biologi Berorientasi Literasi Saintifik. Seminar Nasional Sains \& Entrepreneurship VI (SNSE VI), Universitas PGRI Semarang (UPGRIS). DOI: https://dx.doi.org/10.13140/RG.2.2.13716.86400

Setiawan, Adib Rifqi. (2019, March 23). Upaya Meningkatkan Motivasi Belajar dalam Pembelajaran Ilmu Pengetahuan Alam (IPA) Melalui Bacaan Populer. Seminar Nasional Biologi 2019 Inovasi Penelitian dan Pembelajaran Biologi III (IP2B III), Universitas Negeri Surabaya (UNESA). DOI: https://dx.doi.org/10.13140/RG.2.2.13087.71847

Setiawan, Adib Rifqi. (2019, March 23). Penerapan Pendekatan Saintifik dalam Pembelajaran Biologi sebagai Upaya Melatih Literasi Saintifik Siswa Sekolah Menengah. Seminar Nasional Biologi 2019 Inovasi Penelitian dan Pembelajaran Biologi III (IP2B III), Universitas Negeri Surabaya (UNESA). DOI: https://dx.doi.org/10.13140/RG.2.2.19798.60484

Setiawan, Adib Rifqi. (2019, March 23). Penggunaan Naḍom Mabādī 'Asyroh dalam Pembelajaran Biologi untuk Meningkatkan Motivasi dan Hasil Belajar. Seminar Nasional Biologi 2019 Inovasi Penelitian dan Pembelajaran Biologi III (IP2B III), Universitas Negeri Surabaya (UNESA). DOI: https://dx.doi.org/10.13140/RG.2.2.33220.37763 
Setiawan, Adib Rifqi. (2018, November 24). Penerapan Pendekatan Saintifik untuk Melatih Literasi Saintifik dalam Domain Kompetensi pada Topik Gerak Lurus di Sekolah Menengah Pertama. Seminar Nasional Fisika ke-4 (SiNaFi IV), Universitas Pendidikan Indonesia (UPI). DOI: https://dx.doi.org/10.13140/RG.2.2.23154.04809

Setiawan, Adib Rifqi; Utari, Setiya; Nugraha, Muhamad Gina. (2016, December 17). Mengonstruksi Rancangan Soal Domain Kompetensi Literasi Saintifik Siswa SMP Kelas VIII pada Topik Gerak Lurus. Seminar Nasional Fisika ke-2 (SiNaFi II), Universitas Pendidikan Indonesia (UPI). DOI: https://dx.doi.org/10.13140/RG.2.2.31856.10246/1

Setiawan, Adib Rifqi. (2020, May 12). Introducing the Indonesian Education System. Thesis Commons. DOI: https://doi.org/10.31237/osf.io/ygt5c

Setiawan, A. R. (2020, May 7). Discovering the Fundamental Problem of Four Methods to Analyze Data. Thesis Commons. DOI: https://doi.org/10.31237/osf.io/h953y

Setiawan, Adib Rifqi. (2020, May 6). Menyibak Makna Karya Fadhilaturrahmi. LIS Scholarship Archive. DOI: https://doi.org/10.31229/osf.io/65y4z

Setiawan, Adib Rifqi. (2020, May 6). Discovering the Meaning of Fadhilaturrahmi's Work. Thesis Commons. DOI: https://doi.org/10.31237/osf.io/krf7z

Feldman, DarHalevy; \& Setiawan, Adib Rifqi. (2020, April 24). Education in Israel. Thesis Commons. DOI: https://doi.org/10.31237/osf.io/62shg

Setiawan, Adib Rifqi. (2020, April 18). Musyāfahah al-Qur'ān Melalui Media Elektronik. Thesis Commons. URL: https://thesiscommons.org/ntjp9/

Setiawan, Adib Rifqi. (2020, April 14). Jalāl al-Dīn ‘Abd al-Roḥmān ibn Abī Bakr al-Suyūṭ̂̄. SocArXiv. DOI: https://doi.org/10.31235/osf.io/5zf9v

Setiawan, Adib Rifqi. (2020, April 14). Commodification of the Sexuality in Kim Kardashian's Instagram Posts. SocArXiv. DOI: https://doi.org/10.31235/osf.io/kd6au

Velasufah, Whasfi; \& Setiawan, Adib Rifqi. (2020, April 13). Nilai Pesantren Sebagai Dasar Pendidikan Karakter. Thesis Commons. DOI: https://doi.org/10.31237/osf.io/hq6kz

Setiawan, Adib Rifqi. (2020, April 13). Commodification of the Sexuality in Kim Kardashian's Instagram Posts. Thesis Commons. URL: https://thesiscommons.org/mf7nw/

Setiawan, Adib Rifqi. (2020, April 13). مبادئ اللغة العربية. Thesis Commons. DOI: https://doi.org/10.31237/osf.io/2gvjf

Siayah, Syarofis; \& Setiawan, Adib Rifqi. (2020, April 13). A Brief Explanation of Science Education. EdArXiv. DOI: https://doi.org/10.35542/osf.io/2evn3

Siayah, Syarofis; \& Setiawan, Adib Rifqi. (2020, April 13). A Brief Explanation of Science Education. Thesis Commons. DOI: https://doi.org/10.31237/osf.io/wkvsn

Setiawan, Adib Rifqi; \& Ilmiyah, Surotul. (2020, April 13). Multiple Intelligences Based on Neuroscience. Thesis Commons. DOI: https://doi.org/10.31237/osf.io/e9fyu

Setiawan, Adib Rifqi; \& Ilmiyah, Surotul. (2020, April 13). Kecerdasan Majemuk Berdasarkan Neurosains. EdArXiv. DOI: https://doi.org/10.35542/osf.io/rj2fe 
Setiawan, Adib Rifqi. (2020, April 9). Islamic Education in Southeast Asia. EdArXiv. DOI: https://doi.org/10.35542/osf.io/dnjqv

Setiawan, Adib Rifqi. (2020, April 9). Islamic Education in Southeast Asia. Thesis Commons. DOI: https://doi.org/10.31237/osf.io/e794d

Ilmiyah, Surotul; \& Setiawan, Adib Rifqi. (2020, April 7). Students' Worksheet for Distance Learning Based on Scientific Literacy in the Topic Coronavirus Disease 2019 (COVID-19). Thesis Commons. DOI: https://doi.org/10.31237/osf.io/fpg4j

Ilmiyah, Surotul; \& Setiawan, Adib Rifqi. (2020, April 7). Students' Worksheet for Distance Learning Based on Scientific Literacy in the Topic Coronavirus Disease 2019 (COVID-19). EdArXiv. DOI: https://doi.org/10.35542/osf.io/wyz5v

Setiawan, Adib Rifqi; \& Ilmiyah, Surotul. (2020, April 7). Lembar Kegiatan Siswa untuk Pembelajaran Jarak Jauh Berdasarkan Literasi Saintifik pada Topik Penyakit Coronavirus 2019 (COVID-19). EdArXiv. DOI: https://doi.org/10.35542/osf.io/h4632

Setiawan, Adib Rifqi. (2020, April 5). The Arrogant One. Thesis Commons. DOI: https://doi.org/10.31237/osf.io/8nmku

Setiawan, Adib Rifqi. (2020, April 4). Grace Natalie Louisa. SocArXiv. DOI: https://doi.org/10.31235/osf.io/zwf6g

Setiawan, Adib Rifqi. (2020, April 4). Grace Natalie Louisa. Thesis Commons. DOI: https://doi.org/10.31237/osf.io/u3mxv

Setiawan, Adib Rifqi. (2020, April 3). Sharifah Halimah Alaydrus : a female preachers for our time. SocArXiv. DOI: https://doi.org/10.31235/osf.io/zb8qe

Setiawan, Adib Rifqi. (2020, April 2). Desain Pembelajaran untuk Membimbing Siswa Sekolah Dasar dalam Memperoleh Literasi Saintifik. EdArXiv. DOI: https://doi.org/10.35542/osf.io/u59f8

Setiawan, Adib Rifqi. (2020, April 2). What is the Best Way to Analyze Pre-Post Data?. EdArXiv. DOI: https://doi.org/10.35542/osf.io/h4e6q

Setiawan, Adib Rifqi. (2020, April 2). JUPE My Uncut Story. Open Science Framework (OSF). DOI: https://doi.org/10.31219/osf.io/qdxga

Setiawan, Adib Rifqi. (2020, April 1). Syarifah Halimah Alaydrus. Thesis Commons. DOI: https://doi.org/10.31237/osf.io/xbmcs

Setiawan, Adib Rifqi. (2020, April 1). Sharifah Halimah Alaydrus. Thesis Commons. DOI: https://doi.org/10.31237/osf.io/fp79c

Setiawan, Adib Rifqi. (2019, October 8). Biografi Clara Ng Perempuan Penulis Asal Indonesia. PsyArXiv. DOI: https://doi.org/10.31234/osf.io/yk8sx

Setiawan, Adib Rifqi. (2019, December 23). Contoh Langkah Pembelajaran Berorientasi Literasi Saintifik. santrimilenial.net. URL: https://santrimilenial.net/contoh-langkahpembelajaran-berorientasi-literasi-saintifik/ 
Setiawan, Adib Rifqi. (2019, June 14). Deasy Noviyanti, Perempuan Berbadan Defisit Lemak. qureta.com. URL: https://www.qureta.com/next/post/deasy-noviyanti-perempuanberbadan-defisit-lemak

Setiawan, Adib Rifqi. (2018, December 18). Irma Rahma Suwarma. qureta.com. URL: https://www.qureta.com/next/post/irma-rahma-suwarma

Setiawan, Adib Rifqi. (2018, October 05). Karen Armstrong. qureta.com. URL: https://www.qureta.com/next/post/karen-armstrong

Setiawan, Adib Rifqi. (2018, September 17). Lola Zieta Azelien. qureta.com. URL: https://www.qureta.com/next/post/lola-zieta-azelien

Setiawan, Adib Rifqi. (2018, July 16). Rustriningsih, Srikandi Tersisih. qureta.com. URL: https://www.qureta.com/next/post/rustriningsih-srikandi-tersisih

Setiawan, Adib Rifqi. (2018, July 03). Tangis Daniela Hantuchová. qureta.com. URL: https://www.qureta.com/next/post/tangis-daniela-hantuchova

Setiawan, Adib Rifqi. (2018, June 28). Dewi Perssik. qureta.com. URL: https://www.qureta.com/next/post/dewi-perssik

Setiawan, Adib Rifqi. (2018, June 27). Ice. qureta.com. URL: https://www.qureta.com/next/post/ice

Setiawan, Adib Rifqi. (2018, May 24). Fakhrun. qureta.com. URL: https://www.qureta.com/next/post/fakhrun

Setiawan, Adib Rifqi. (2018, April 10). Eny Rochmawati Octaviani: memberikan hiburan, menyuntikkan harapan. Majalah SANTRI, 8: 15-18. URL: https://issuu.com/majalahsantri/docs/majalah_santri_8/17

Setiawan, Adib Rifqi. (2018, April 10). Busana: pemantas raga, pelaras jiwa. Majalah SANTRI, 8: 2627. URL: https://issuu.com/majalahsantri/docs/majalah_santri_8/28

Setiawan, Adib Rifqi. (2018, April 10). Rosa Amalia Iqony: paduan yakin diri dan rendah hati. Majalah SANTRI, 8: 46. URL:

https://issuu.com/majalahsantri/docs/majalah_santri_8/48

Setiawan, Adib Rifqi. (2018, March 25). Novi Kaka: Sahabat, Panutan, Pembimbing. qureta.com. URL: https://www.qureta.com/next/post/novi-kaka-sahabat-panutan-pembimbing

Setiawan, Adib Rifqi. (2018, March 21). Bidadari di Kesunyian itu Bernama Maria Sharapova. qureta.com. URL: https://www.qureta.com/next/post/bidadari-di-kesunyian-itubernama-maria-sharapova

Setiawan, Adib Rifqi. (2018, March 19). Airin Rachmi Diany, Lilin Penerang Masyarakat Urban. qureta.com. URL: https://www.qureta.com/next/post/airin-rachmi-diany-lilinpenerang-masyarakat-urban

Setiawan, Adib Rifqi. (2018, March 19). Kamu dalam Aku: A Brief Story of Park Bom. qureta.com. URL: https://www.qureta.com/next/post/kamu-dalam-aku-a-brief-story-of-parkbom

Setiawan, Adib Rifqi. (2018, March 19). Guru yang Menyapih: Catatan Perjalanan Pribadi Nong Darol Mahmada. qureta.com. URL: https://www.qureta.com/next/post/guru-yangmenyapih-catatan-perjalanan-pribadi-nong-darol-mahmada

Setiawan, Adib Rifqi. (2018, March 17). Maryam Musfiroh: An Educator for Our Time. qureta.com. URL: https://www.qureta.com/next/post/maryam-musfiroh-an-educator-for-ourtime

Setiawan, Adib Rifqi. (2018, March 15). Eny R. Octaviani. qureta.com. URL: https://www.qureta.com/next/post/eny-r-octaviani 
Setiawan, Adib Rifqi. (2018, March 14). Surely You're Joking, Mrs. Ilmy!. qureta.com. URL: https://www.qureta.com/next/post/surely-you-re-joking-mrs-ilmy

Setiawan, Adib Rifqi. (2018, March 14). Meniti Ilmuwati. qureta.com. URL: https://www.qureta.com/next/post/meniti-ilmuwati

Setiawan, Adib Rifqi. (2018, March 12). Clara Ng. qureta.com. URL: https://www.qureta.com/next/post/clara-ng

Setiawan, Adib Rifqi. (2018, March 11). Kisah Kasih Ayah di Balik Mata Najwa. qureta.com. URL: https://www.qureta.com/next/post/kisah-kasih-ayah-di-balik-mata-najwa

Setiawan, Adib Rifqi. (2018, March 11). Rosa Amalia Iqony. qureta.com. URL: https://www.qureta.com/next/post/rosa-amalia-iqony

Setiawan, Adib Rifqi. (2018, March 10). Venice Min. qureta.com. URL: https://www.qureta.com/next/post/venice-min

Setiawan, Adib Rifqi. (2018, March 09). Ketika YoonA Menyaksikan Real Madrid Menghempaskan PSG. qureta.com. URL: https://www.qureta.com/next/post/ketika-yoonamenyaksikan-real-madrid-menghempaskan-psg

Setiawan, Adib Rifqi. (2018, March 09). Kepedulian Airin Rachmi Diany pada Pendidikan. qureta.com. URL: https://www.qureta.com/next/post/kepedulian-airin-rachmidiany-pada-pendidikan

Setiawan, Adib Rifqi. (2018, March 09). Laila Fariha Zein (a.k.a. Uus atau Febi). qureta.com. URL: https://www.qureta.com/next/post/laila-fariha-zein-febi

Setiawan, Adib Rifqi. (2018, March 09). Pantat Perekat Umat. qureta.com. URL: https://www.qureta.com/next/post/pantat-perekat-umat

Setiawan, Adib Rifqi. (2018, March 09). Sisi Religi Grace Natalie. qureta.com. URL: https://www.qureta.com/next/post/sisi-religi-grace-natalie

Setiawan, Adib Rifqi. (2018, March 09). Asal Usul Nama Via Vallen. qureta.com. URL: https://www.qureta.com/next/post/asal-usul-nama-via-vallen

Setiawan, Adib Rifqi. (2018, March 07). Mengenal Oza Kioza. qureta.com. URL: https://www.qureta.com/next/post/mengenal-oza-kioza

Setiawan, Adib Rifqi. (2018, March 06). Menyoal Vokal Duo Serigala. qureta.com. URL: https://www.qureta.com/next/post/menyoal-vokal-duo-serigala

Setiawan, Adib Rifqi. (2018, March 06). Breast Capital. qureta.com. URL: https://www.qureta.com/next/post/breast-capital

Amatullah; \& Setiawan, Adib Rifqi. (2017, October 10). Nadirsyah Hosen: berkarya sebagai diaspora. Majalah SANTRI, 7: 56-59. URL:

https://issuu.com/majalahsantri/docs/santri_edisi_7/58

Setiawan, Adib Rifqi. (2017, June 03). Dari Yuli Hingga Julia. qureta.com. URL: https://www.qureta.com/next/post/dari-yuli-hingga-julia-2

Setiawan, Adib Rifqi. (2017, June 02). Aisha. qureta.com. URL: https://www.qureta.com/next/post/aisha-humaira

Setiawan, Adib Rifqi. (2015, November 10). Kehidupan Asmara Hawking: raga lumpuh, jiwa masih bisa tersentuh. fisikanet.lipi.go.id. URL:

http://www.fisikanet.lipi.go.id/utama.cgi?artikel\&1447145876\&2 
Setiawan, Adib Rifqi. (2015, November 07). Dibalik Sampul Buku A Brief History of Time, agar pengetahuan tak hanya dinikmati ilmuwan. fisikanet.lipi.go.id. URL:

http://www.fisikanet.lipi.go.id/utama.cgi?artikel\&1446855103\&2

Setiawan, Adib Rifqi. (2015, November 03). Dibalik Nama Besar Albert Einstein: Dari Politik, Asmara, hingga Matematika. fisikanet.lipi.go.id. URL:

http://www.fisikanet.lipi.go.id/utama.cgi?artikel\&1446556354\&2

Setiawan, Adib Rifqi. (2015, October 31). Kurir Mikroskopis Alam Semesta bukan debu biasa. fisikanet.lipi.go.id. URL:

http://www.fisikanet.lipi.go.id/utama.cgi?artikel\&1446304060\&2

Setiawan, Adib Rifqi. (2015, October 10). 10 Kejutan Subatomik. fisikanet.lipi.go.id. URL: http://www.fisikanet.lipi.go.id/utama.cgi?artikel\&1444577286\&3 